\title{
Long-Lasting Effect of Infant Rats Endotoxemia on Heat Shock Protein 60 in the Pancreatic Acinar Cells: Involvement of Toll-Like Receptor 4
}

\author{
Joanna Bonior, ${ }^{1}$ Jolanta Jaworek, ${ }^{1}$ Michalina Kot, ${ }^{1}$ \\ Stanisław J. Konturek, ${ }^{2}$ and Piotr Pierzchalski ${ }^{1}$ \\ ${ }^{1}$ Department of Medical Physiology, Faculty of Health Sciences, School of Medicine, Jagiellonian University, Michalowskiego 12 Street, \\ 31-126 Krakow, Poland \\ ${ }^{2}$ Physiology Medical Faculty, School of Medicine, Jagiellonian University, Grzegorzecka 16 Street, 31-531 Krakow, Poland
}

Correspondence should be addressed to Joanna Bonior, joanna.bonior@uj.edu.pl

Received 23 December 2011; Revised 10 March 2012; Accepted 14 March 2012

Academic Editor: Zoltan Rakonczay

Copyright (C 2012 Joanna Bonior et al. This is an open access article distributed under the Creative Commons Attribution License, which permits unrestricted use, distribution, and reproduction in any medium, provided the original work is properly cited.

Introduction. Lipopolysaccharide endotoxin (LPS) is responsible for septic shock and multiorgan failure, but pretreatment of rats with low doses of LPS reduced pancreatic acute damage. Aim. We investigated the effects of the endotoxemia induced in the early period of life on Toll-like receptor 4 (TLR4), heat shock protein 60 (HSP60) and proapoptotic Bax, caspase-9 and -3 or antiapoptotic Bcl-2 protein expression in the pancreatic acinar cells of adult animals. Material and Methods. Newborn rats ( $25 \mathrm{~g}$ ) were injected with endotoxin (Escherichia coli) for 5 consecutive days. Two months later, pancreatic acinar cells were isolated from all groups of animals and subjected to caerulein stimulation $\left(10^{-8} \mathrm{M}\right)$. Protein expression was assessed employing Western blot. For detection of apoptosis we have employed DNA fragmentation ladder assay. Results. Preconditioning of newborn rats with LPS increased TLR4, Caspase-9 and -3 levels, but failed to affect basal expression of HSP60, Bax, and Bcl-2. Subsequent caerulein stimulation increased TLR4, Bcl-2, and caspases, but diminished HSP60 and Bax proteins in pancreatic acinar cells. Endotoxemia dose-dependently increased TLR4, Bax, HSP60, and both caspases protein signals in the pancreatic acini, further inhibiting antiapoptotic Bcl-2. Conclusions. Endotoxemia promoted the induction of HSP60 via TLR4 in the infant rats and participated in the LPS-dependent pancreatic tissue protection against acute damage.

\section{Introduction}

Lipopolysaccharide (LPS, endotoxin), which is a constituent of the outer membrane of gram-negative bacteria, plays a very important role in the pathogenesis of septic shock [1]. LPS is the pivotal stimulus for triggering an inflammatory cascade in macrophages via Toll-like receptor 4 (TLR4). LPS has also been identified as a ligand for TLR4 and takes a part in the pathophysiology of the sepsis syndrome [2-4]. Several pathways of endotoxin signal transduction have been suggested in case of endotoxin stimulation of the cell.

Toll-like receptors (TLRs), originally identified as homologues of Drosophila Toll, belong to the superfamily of interleukin-1 receptors [5]. TLRs are the most important family of pattern recognition receptors (PRRs) $[6,7]$. The existence of several TLRs enables the innate immunity system to recognize different groups of pathogens while initiating appropriate and distinct immunological responses, according to the pathogen-associated molecular patterns (PAMPs) [8]. TLR4 proteins are expressed on the cell surface becoming the receptors for the Gram-negative bacteria cell membrane components, LPS. Stimulation of TLR4 by LPS is a complex process, which includes the participation of several molecules like LPS binding protein (LBP), CD14, and MD-2 $[9,10]$. TLR4 might participate in the induction of both protective and harmful effects on the tissues. Beside TLR4, other ligands of TLR4, like hyaluronan, induce an immunological response initiating epithelia repair but in some cases TLR4 are involved in conveying of an endogenous 
danger signals mobilizing high-mobility group box-1 protein or in response to free fatty acids what results in tissue damage [11-13]. Some reports point out the possibility of TRLR4 involvement in response to heat shock protein 60 (HSP60) as an endogenous ligand TLR4 [14].

HSP60 is involved in the protein folding, assembly, disassembly, and degradation under normal conditions. This protein, similar to other HSPs, is increased during cellular stress as an adaptive protection strategy [15]. Over the past decade investigators found that HSP60 and the pancreatic enzymes share a common location inside the pancreatic acinar cells, interacting intimately $[16,17]$. Moreover, like the distributive characteristics of pancreatic enzymes, HSP60 showed an increasing gradient of collocation along the pancreatic secretory pathway from the rough endoplasmic reticulum and Golgi apparatus to zymogen granules in the acinar cells [16]. An increased transcription and production of HSP60 with protective action has been suggested in pancreatitis [18-20].

Acute pancreatitis (AP) is an emergent disease commonly seen in the clinical practice but its complicated pathogenesis is still incomprehensible. Scientists are in agreement that AP involves a cascade of events, and numerous reports have suggested that its initial step is the activation of trypsinogen inside the pancreatic acinar cells, resulting in damages evoked by the activated pancreatic enzyme $[21,22]$. As to the mechanism of the abnormal enzyme activation, a number of theories have been considered, for instance: calcium overload or cathepsin B activation $[23,24]$. A new theory advocates that HSP60 plays an important role in the protection of pancreatic tissues against damages and malfunctioning or weakening of HSP60 effect under physiological conditions is responsible for the early zymogen activation in AP $[15,24]$.

It has been shown that low doses of endotoxin (LPS) could protect the pancreas against caerulein-induced pancreatitis (CIP) [25-28]. Endotoxemia in the suckling rats attenuates acute pancreatitis and impairment of the exocrine function in vitro and in vivo models at adult age [29-32].

The aim of this study was to investigate in the pancreatic acinar cells isolated from adult animals, the effects of foregoing infant rats endotoxemia on TLR4, HSP60 and pro-apoptotic Bax, caspase- 9 and -3 or antiapoptotic Bcl-2 protein expression.

\section{Material and Methods}

Studies were performed on male Wistar rats (weighing: newborn $25 \mathrm{~g}$; adult: 170-200 g). Animals were housed in cages under standard conditions, on commercial pellet chow at water ad libitum, at room temperature with a 12-h light and dark cycle.

2.1. Reagents. Lipopolysaccharide from Sigma-Aldrich Co. (St. Louis, MO, USA) and caerulein (Takus) from Pharmacia $\mathrm{GmbH}$, Erlangen, Germany, were used for the experiments.

2.2. Experimental Protocol. The experimental protocol was divided into two general parts: in vivo and in vitro researches.

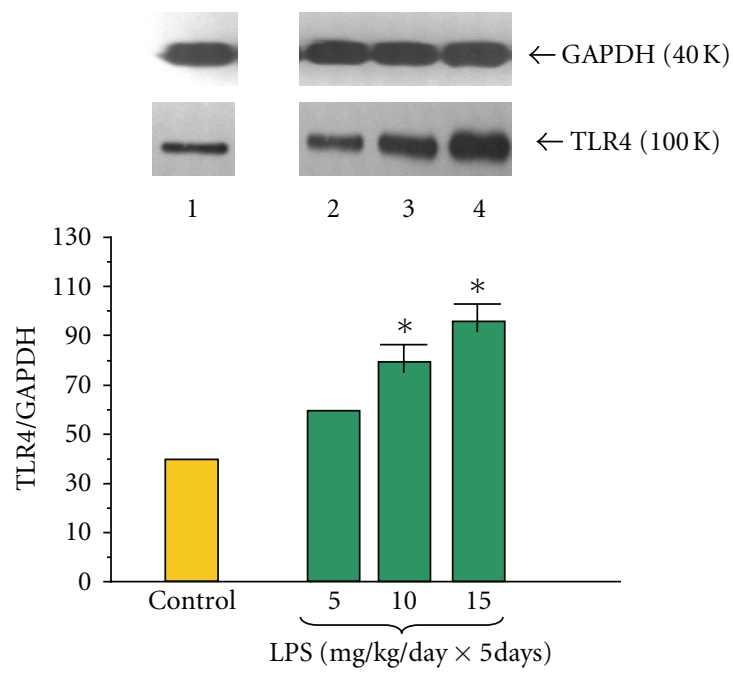

FIGURE 1: Western blot analysis of TLR4 protein level in the adult rat pancreatic acinar cells under basal conditions (lane 1), treated in the infant animals by lipopolysaccharide (Escherichia coli) at the doses of $5 \mathrm{mg} / \mathrm{kg} /$ day $\times 5$ days (lane 2 ), $10 \mathrm{mg} / \mathrm{kg} /$ day $\times 5$ days (lane 3 ), and $15 \mathrm{mg} / \mathrm{kg} /$ day $\times 5$ days (lane 4 ) after 5 hours of incubation. Asterisk indicates significant $(P<0.05)$ change, as compared to the control group. The blots were stripped and probed with GAPDH to document equal protein loading. All presented results were obtained in 4 consecutive experiments and are representative for the observed phenomenon.

2.3. In Vivo Experiments. Newborn rats weighing $25 \mathrm{~g}$ were employed and divided into five main groups:

(1) control group: rats were injected with $200 \mu \mathrm{L}$ of vehicle saline intraperitoneally (i.p.), once a day, during 5 consecutive days.

(2) LPS (Escherichia coli) group: rats were treated with LPS dissolved in $200 \mu \mathrm{L}$ of vehicle saline, and animals were subjected to i.p. injection once a day, during 5 consecutive days. This rats were divided into three separate subgroups which were treated with a single dose of LPS:

2.1 group: $5 \mathrm{mg} / \mathrm{kg} /$ day $\times 5$ days (total dose $25 \mathrm{mg} / \mathrm{kg}$ );

2.2 group: $10 \mathrm{mg} / \mathrm{kg} /$ day $\times 5$ days (total dose $50 \mathrm{mg} / \mathrm{kg}$ );

2.3 group: $15 \mathrm{mg} / \mathrm{kg} /$ day $\times 5$ days (total dose $75 \mathrm{mg} / \mathrm{kg}$ ).

Each part of the study consists of several experimental groups of rats, $6-8$ rats in each single group.

2.4. In Vitro Experiments. Two months following the injection of both vehicle saline or LPS solution, at adult age of animals, the pancreatic acinar cells were isolated by collagenase digestion as described previously $[33,34]$ and subjected to increasing concentration of caerulein $\left(10^{-12}\right.$, $10^{-10}$ or $\left.10^{-8} \mathrm{M}\right)$. The cells were incubated in the presence of tested substance for: $0,0.5,1,3,5$, or $7 \mathrm{~h}$. Subsequently, $10^{-8} \mathrm{M}$ concentrations of caerulein were found to be the most effective (data not shown) and selected for further experiments. Time-course experiments have shown that $5 \mathrm{~h}$ incubation time was the most effective and has been picked 


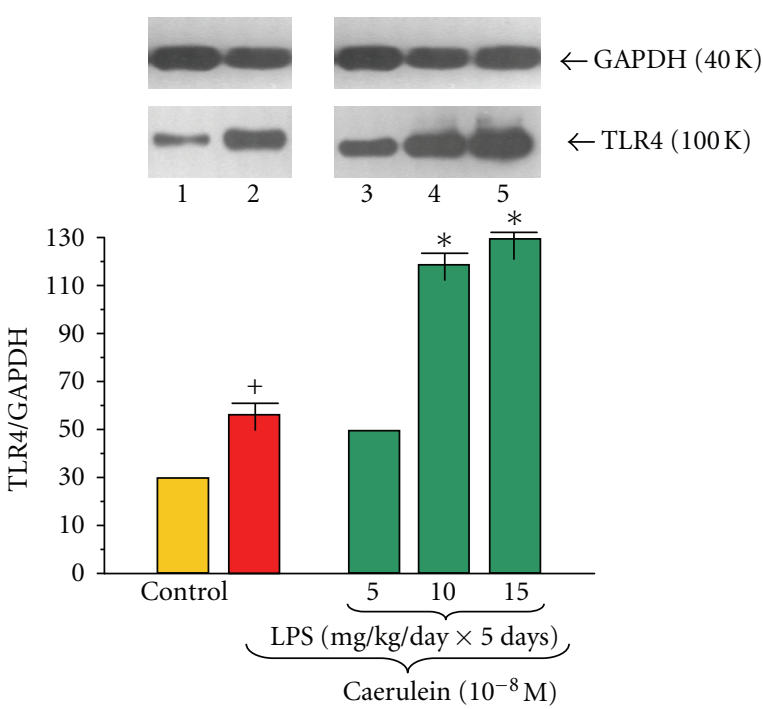

FIgURE 2: Western blot analysis of TLR4 protein level in the adult rat pancreatic acinar cells under basal conditions (lane 1), stimulated in vitro by caerulein at the dose of $10^{-8} \mathrm{M}$ (lane 2), treated in the infant animals by lipopolysaccharide (Escherichia coli) at the doses of $5 \mathrm{mg} / \mathrm{kg} /$ day $\times 5$ days + caerulein $10^{-8} \mathrm{M}$ (lane 3 ), $10 \mathrm{mg} / \mathrm{kg} /$ day $\times 5$ days + caerulein $10^{-8} \mathrm{M}$ (lane 4 ), and $15 \mathrm{mg} / \mathrm{kg} /$ day $\times 5$ days + caerulein $10^{-8} \mathrm{M}$ (lane 5 ) after 5 hours of incubation. Cross indicates significant $(P<0.05)$ change, as compared to the control group. Asterisk indicates significant $(P<0.05)$ change, as compared to the value obtained from the rats treated by increasing doses of LPS $(10$ or $15 \mathrm{mg} / \mathrm{kg} / \mathrm{day} \times$ 5 days) in combination with caerulein $\left(10^{-8} \mathrm{M}\right)$, as compared to the caerulein $\left(10^{-8} \mathrm{M}\right)$ alone stimulation. The blots were stripped and probed with GAPDH to document equal protein loading. All presented results were obtained in 4 consecutive experiments and are representative for the observed phenomenon.

out for all further part of the study (data not shown). All the experiments were repeated at last three times. The results presented here were taken from the most representative experiments.

All experimental procedures performed in this study were approved by the Jagiellonian University Ethical Committee for Animals Experimentation.

2.5. Western Blot. The whole-cell extracts were prepared as described elsewhere [35]. Equal load of protein in each sample was assessed using QantiPro BCA Assay Kit (Sigma, USA). Protein samples were boiled with Western blot sample buffer and loaded on the 12\% SDS-polyacrylamide gel. After electrophoresis and transfer of the samples, the PVDF membrane (BioRad, USA) was blocked with blocking buffer (5\% non-fat dried milk in PBS) for $1 \mathrm{~h}$ in room temperature. Blocking procedure was followed with $1 \mathrm{~h}$ exposure to primary antibody diluted 1:1000 and secondary antibody diluted 1:1000 in blocking buffer.

After each antibody probing membrane was washed three times for $15 \mathrm{~min}$. in TBST buffer $(0,1 \mathrm{M}$ Tris $\mathrm{pH} 8,0 ; 1,5 \mathrm{M}$ $\mathrm{NaCl} ; 0,5 \%$ TritonX-100). Detection of membrane bound proteins was performed using $\mathrm{BM}$ Chemiluminescence
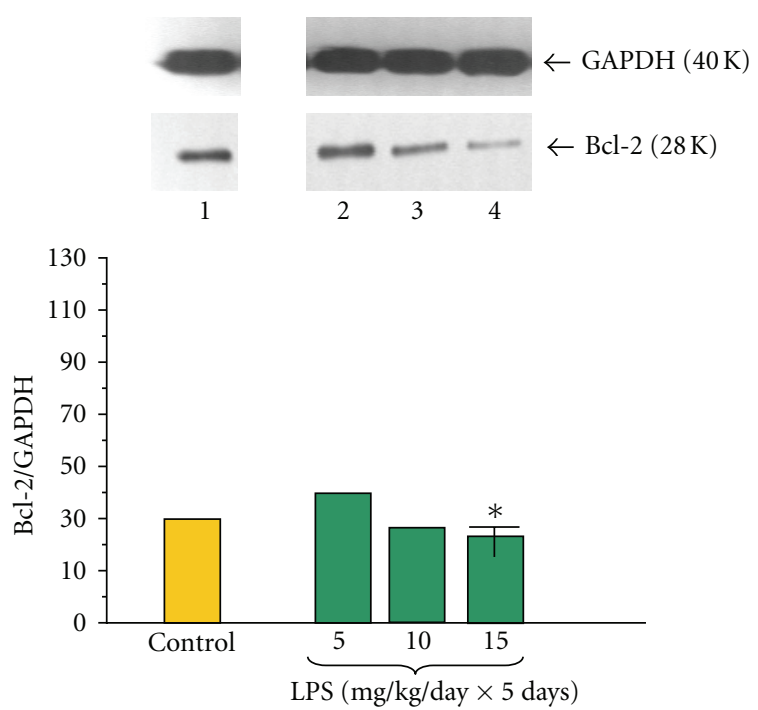

FIGURE 3: Western blot analysis of Bcl-2 protein level in the adult rat pancreatic acinar cells under basal conditions (lane 1), treated in the infant animals by lipopolysaccharide (Escherichia coli) at the doses of $5 \mathrm{mg} / \mathrm{kg} /$ day $\times 5$ days (lane 2 ), $10 \mathrm{mg} / \mathrm{kg} /$ day $\times 5$ days (lane 3 ), and $15 \mathrm{mg} / \mathrm{kg} /$ day $\times 5$ days (lane 4 ) after 5 hours of incubation. Asterisk indicates significant $(P<0.05)$ change, as compared to the control group. The blots were stripped and probed with GAPDH to document equal protein loading. All presented results were obtained in 4 consecutive experiments and are representative for the observed phenomenon.

Blotting Substance (Boehringer, Mannheim, Germany). The blots were stripped and probed with GAPDH to document equal protein loading. All presented results were obtained in 4 consecutive experiments and are representative for the observed phenomenon. The following items used in the Western blot reactions were purchased from Santa Cruz Biotechnology (Santa Cruz): antibodies mouse monoclonal anti-HSP60 $\operatorname{IgG}_{1}[\mathrm{sc}-136291]$, mouse monoclonal anti-caspase $9 \mathrm{IgG}_{1}$ [sc-81663], mouse monoclonal anti-Bcl$2 \mathrm{IgG}_{1}$ [sc-7382], mouse monoclonal anti-Bax IgG $\mathrm{Igs}_{1}$ 70408], mouse monoclonal anti-GADPH IgG 1 [sc-137179], goat polyclonal anti-caspase $3 \mathrm{IgG}$ [sc-1225], rabbit polyclonal anti-TLR4 IgG [sc-30002], rabbit anti-goat IgG HRP [sc-2768], and goat anti-mouse $\operatorname{IgG}_{1}-\mathrm{HRP}$ [sc-2060], goat anti-rabbit IgG-HRP [sc-2030].

2.6. DNA Fragmentation. To analyze DNA fragmentation due to induced apoptosis, cells $\left(5 \times 10^{6} /\right.$ sample) were lyzed with $150 \mu \mathrm{L}$ hypotonic lysis buffer (edetic acid $10 \mathrm{mM}, 0.5 \%$ Triton X-100, Tris-HCl, pH 7.4) for 15 min. on ice and were precipitated with $2.5 \%$ polyethylene glycol and $1 \mathrm{M} \mathrm{NaCl}$ for $15 \mathrm{~min}$. at $4^{\circ} \mathrm{C}$. After centrifugation at $13000 \times \mathrm{g}$ for $10 \mathrm{~min}$. at room temperature, the supernatant was treated with proteinase $\mathrm{K}(0.3 \mathrm{~g} / \mathrm{L})$ at $37^{\circ} \mathrm{C}$ for $1 \mathrm{~h}$ and precipitated with isopropanol at $20^{\circ} \mathrm{C}$. Centrifuged pellets were dissolved in $10 \mu \mathrm{L}$ of Tris-EDTA (pH 7.6) and analyzed employing electrophoresis in a $1.5 \%$ agarose gel containing ethidium bromide. DNA pattern was visualized under ultraviolet light. 

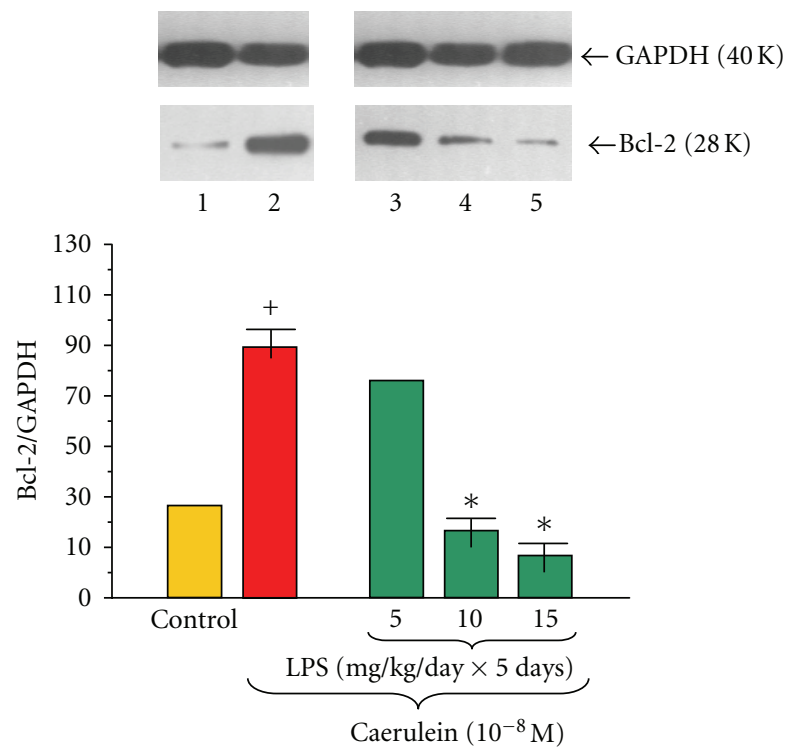

FIGURE 4: Western blot analysis of Bcl-2 protein level in the adult rat pancreatic acinar cells under basal conditions (lane 1), stimulated in vitro by caerulein at the dose of $10^{-8} \mathrm{M}$ (lane 2), treated in the infant animals by lipopolysaccharide (Escherichia coli) at the doses of $5 \mathrm{mg} / \mathrm{kg} /$ day $\times 5$ days + caerulein $10^{-8} \mathrm{M}$ (lane 3 ), $10 \mathrm{mg} / \mathrm{kg} /$ day $\times$ 5 days + caerulein $10^{-8} \mathrm{M}$ (lane 4 ), and $15 \mathrm{mg} / \mathrm{kg} /$ day $\times 5$ days + caerulein $10^{-8} \mathrm{M}$ (lane 5) after 5 hours of incubation. Cross indicates significant $(P<0.05)$ change, as compared to the control group. Asterisk indicates significant $(P<0.05)$ change, as compared to the value obtained from the rats treated by increasing doses of LPS ( 10 or $15 \mathrm{mg} / \mathrm{kg} /$ day $\times 5$ days) in combination with caerulein $\left(10^{-8} \mathrm{M}\right)$, as compared to the caerulein $\left(10^{-8} \mathrm{M}\right)$ alone stimulation. The blots were stripped and probed with GAPDH to document equal protein loading. All presented results were obtained in 4 consecutive experiments and are representative for the observed phenomenon.

2.7. Statistical Analysis. All experiments were performed in triplicates. Results are expressed as means \pm SEM. Statistical analysis was performed using analysis on variance and twoway ANOVA test when appropriate. Differences with $P<$ 0.05 were considered as significant.

\section{Results}

The Study of the Effects of Lipopolysaccharide (Escherichia coli) and/or Caerulein on TLR4, Bcl-2, Bax, HSP60, Caspase-9, and Caspase-3 Protein Level and Apoptosis in the Pancreatic Acinar Cells.

The amount of Toll-like receptor 4 (TLR4) proteins in the pancreatic acinar cells at adult rats was determined in all examined samples (Figures 1 and 2). The ratio of TLR4/GAPDH protein level in the control group was $40.0 \pm 0.2$ and significantly dose-dependently increased in the group of rats treated at early period of life with 5,10 or $15 \mathrm{mg} / \mathrm{kg} /$ day doses of LPS for 5 consecutive days. The highest abundance of protein was detected in the cell samples from animals treated with LPS at doses of 10 or $15 \mathrm{mg} / \mathrm{kg} / \mathrm{day}$ and the ratio of TLR4/GAPDH reached $79.0 \pm 0.4$ and $98.0 \pm$ 0.4 , respectively (Figure 1).

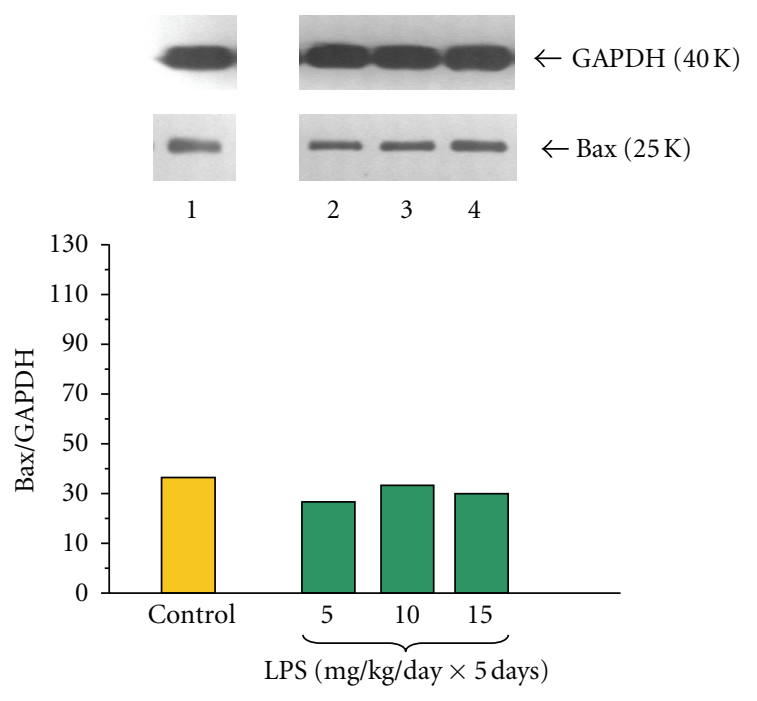

Figure 5: Western blot analysis of Bax protein level in the adult rat pancreatic acinar cells under basal conditions (lane 1), treated in the infant animals by lipopolysaccharide (Escherichia coli) at the doses of $5 \mathrm{mg} / \mathrm{kg} /$ day $\times 5$ days (lane 2 ), $10 \mathrm{mg} / \mathrm{kg} /$ day $\times 5$ days (lane 3 ), and $15 \mathrm{mg} / \mathrm{kg} /$ day $\times 5$ days (lane 4 ) after 5 hours of incubation. The blots were stripped and probed with GAPDH to document equal protein loading. All presented results were obtained in 4 consecutive experiments and are representative of the observed phenomenon.

Application of caerulein $\left(10^{-8} \mathrm{M}\right)$ to the acinar cells significantly upregulated TLR4 protein level, as compared to the control group with ratio of TLR4/GAPDH $58.0 \pm 0.3$ after 5 hours of incubation (Figure 2).

Endotoxemia in the newborn rats induced by increasing doses of LPS $(5,10$ or $15 \mathrm{mg} / \mathrm{kg} /$ day $\times 5$ days $)$ resulted in significant and dose-dependent increase of TLR4 protein level in the acini incubated with caerulein $\left(10^{-8} \mathrm{M}\right)$ as compared to the group subjected to caerulein alone. The most significant increase was detected in the cells isolated from rats treated with LPS at doses of 10 or $15 \mathrm{mg} / \mathrm{kg} /$ day. The ratio of TLR4/GAPDH in these groups extended to $119.0 \pm 0.4$ and $130.0 \pm 0.4$, respectively (Figure 2 ).

An antiapoptotic mitochondrial molecule $\mathrm{Bcl}-2$ was detected in all examined samples of pancreatic acinar cells obtained from adult animals (Figures 3 and 4). The ratio of Bcl-2/GAPDH proteins in the control group was $29.00 \pm$ 0.2 and significantly in dose-dependent manner decreased in the group of rats treated priorly with LPS at dose of $15 \mathrm{mg} / \mathrm{kg} /$ day $\times 5$ days. The ratio of Bcl-2/GAPDH reached $22.0 \pm 0.1$ (Figure 3).

Application of caerulein $\left(10^{-8} \mathrm{M}\right)$ to the acinar cells obtained from the control rats resulted in the significant upregulation of $\mathrm{Bcl}-2$ protein level, as compared to the control, untreated with caerulein culture. The ratio of Bcl2/GAPDH was $89.0 \pm 0.3$ after 5 hours of incubation (Figure 4).

Endotoxemia in the sucking animals caused by increasing doses of LPS $(5,10$ or $15 \mathrm{mg} / \mathrm{kg} /$ day $\times 5$ days $)$ in significant and dose-dependent way downregulated Bcl-2 protein level in the pancreatic acini incubated with caerulein $\left(10^{-8} \mathrm{M}\right)$ 


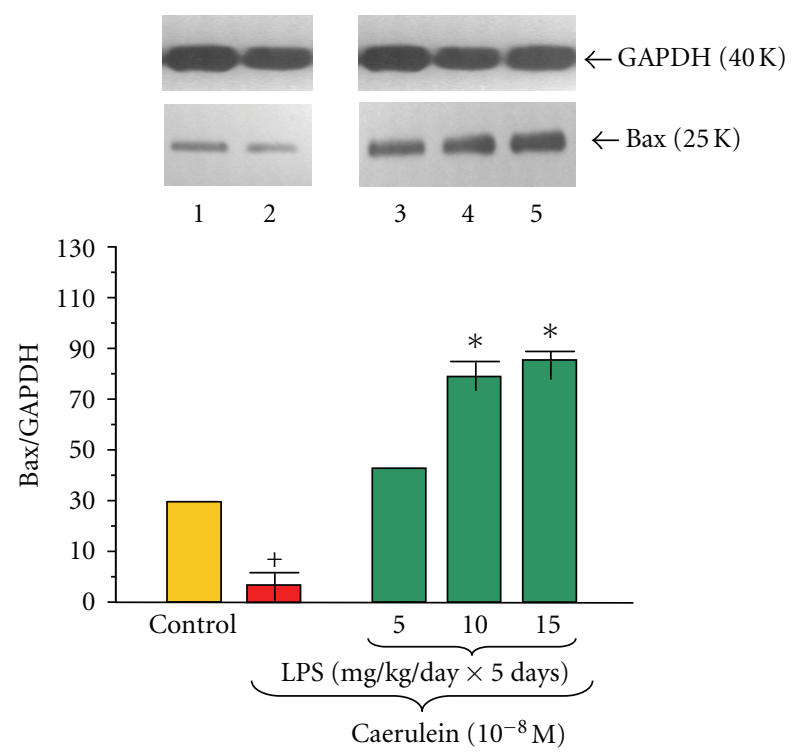

Figure 6: Western blot analysis of Bax protein level in the adult rat pancreatic acinar cells under basal conditions (lane 1), stimulated in vitro by caerulein at the dose of $10^{-8} \mathrm{M}$ (lane 2), treated in the infant animals by lipopolysaccharide (Escherichia coli) at the doses of $5 \mathrm{mg} / \mathrm{kg} /$ day $\times 5$ days + caerulein $10^{-8} \mathrm{M}$ (lane 3 ), $10 \mathrm{mg} / \mathrm{kg} /$ day $\times$ 5 days + caerulein $10^{-8} \mathrm{M}$ (lane 4 ), and $15 \mathrm{mg} / \mathrm{kg} /$ day $\times 5$ days + caerulein $10^{-8} \mathrm{M}$ (lane 5) after 5 hours of incubation. Cross indicates significant $(P<0.05)$ change, as compared to the control group. Asterisk indicates significant $(P<0.05)$ change, as compared to the value obtained from the rats treated by increasing doses of LPS $(10$ or $15 \mathrm{mg} / \mathrm{kg} /$ day $\times 5$ days) in combination with caerulein $\left(10^{-8} \mathrm{M}\right)$, as compared to the caerulein $\left(10^{-8} \mathrm{M}\right)$ alone stimulation. The blots were stripped and probed with GAPDH to document equal protein loading. All presented results were obtained in 4 consecutive experiments and are representative of the observed phenomenon.

as compared to the caerulein-treated group alone. The strongest signal was detected in the acini gained from animals treated with LPS at doses of 10 or $15 \mathrm{mg} / \mathrm{kg} /$ day. The ratio in these groups of $\mathrm{Bcl}-2 / \mathrm{GAPDH}$ reached $17.0 \pm 0.1$ and $08.0 \pm 0.05$ respectively (Figure 4 )

The proapoptotic mitochondrial Bax protein level in pancreatic acinar cells obtained from adult animals was detected in all examined samples (Figures 5 and 6). The ratio of Bax/GAPDH protein level in the control group was $38.00 \pm 0.2$ and did not change in the group treated priorly with increasing doses of LPS 5,10 or $15 \mathrm{mg} / \mathrm{kg} /$ day $\times 5$ days (Figure 5).

Incubation of the pancreatic acinar cells with caerulein $\left(10^{-8} \mathrm{M}\right)$ caused a significant decrease of Bax protein level, as compared to the untreated with caerulein control. The ratio of Bax/GAPDH protein in this group was $3.5 \pm 0.05$ after 5 hours of incubation (Figure 6).

Endotoxemia in the newborn rats due to increasing doses of LPS $(5,10$ or $15 \mathrm{mg} / \mathrm{kg} /$ day $\times 5$ days $)$ caused significant and dose-dependent increase of Bax protein level in the acini incubated with caerulein $\left(10^{-8} \mathrm{M}\right)$. The strongest signals were detected in the animals treated with 10 or $15 \mathrm{mg} / \mathrm{kg} /$ day of LPS. In these groups the ratio of Bax/GAPDH reached

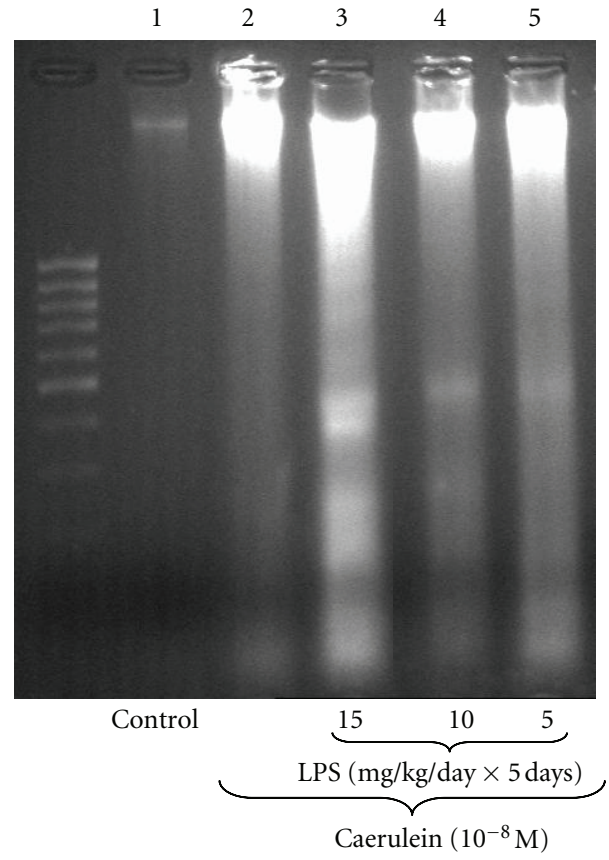

Figure 7: Analysis of DNA fragmentation pattern in the adult rat pancreatic acinar cells under basal conditions (lane 1), stimulated in vitro by caerulein at the dose of $10^{-8} \mathrm{M}$ (lane 2), treated in the infant animals by lipopolysaccharide (Escherichia coli) at the doses of $15 \mathrm{mg} / \mathrm{kg} /$ day $\times 5$ days + caerulein $10^{-8} \mathrm{M}$ (lane $3), 10 \mathrm{mg} / \mathrm{kg} /$ day $\times 5$ days + caerulein $10^{-8} \mathrm{M}$ (lane 4 ), and $5 \mathrm{mg} / \mathrm{kg} /$ day $\times 5$ days + caerulein $10^{-8} \mathrm{M}$ (lane 5 ) after 5 hours of incubation. All presented results were obtained in 4 consecutive experiments and are representative of the observed phenomenon.

$80.0 \pm 0.4$ and $87.0 \pm 0.4$, respectively (Figure 6). The data obtained in DNA fragmentation ladder assay correspond with the results of the analysis of apoptosis-related proteins, revealing the strongest pattern of DNA apoptotic damage in the cultures of pancreatic acini isolated from animals preconditioned with highest doses of LPS and subjected to caerulein $\left(10^{-8} \mathrm{M}\right)$ stimulation (Figure 7 lane 3$)$. In the control cultures of pancreatic acini and those subjected to caerulein stimulation without foregoing preconditioning with LPS no apoptosis-related DNA damage pattern was observed (Figure 7 lanes 1,2).

The HSP60 protein level was detected in all examined samples of pancreatic acinar cells obtained from adult animals (Figures 8 and 9). The ratio of HSP60/GAPDH protein level in the control group was $63.00 \pm 0.3$ and failed to change in the group treated at infancy by increasing doses of LPS 5,10 or $15 \mathrm{mg} / \mathrm{kg} /$ day $\times 5$ days (Figure 8 ).

Addition of caerulein $\left(10^{-8} \mathrm{M}\right)$ to the pancreatic acinar cell culture obtained from untreated with LPS animals significantly decreased protein level of HSP60, as compared to the control group. The ratio of HSP60/GAPDH was $19.0 \pm$ 0.03 after 5 hours of incubation (Figure 9).

To the contrary, endotoxemia in the suckling rats produced significant increase of HSP60 protein level detected in the acini culture incubated with caerulein $\left(10^{-8} \mathrm{M}\right)$, as compared to the cells subjected to caerulein alone 

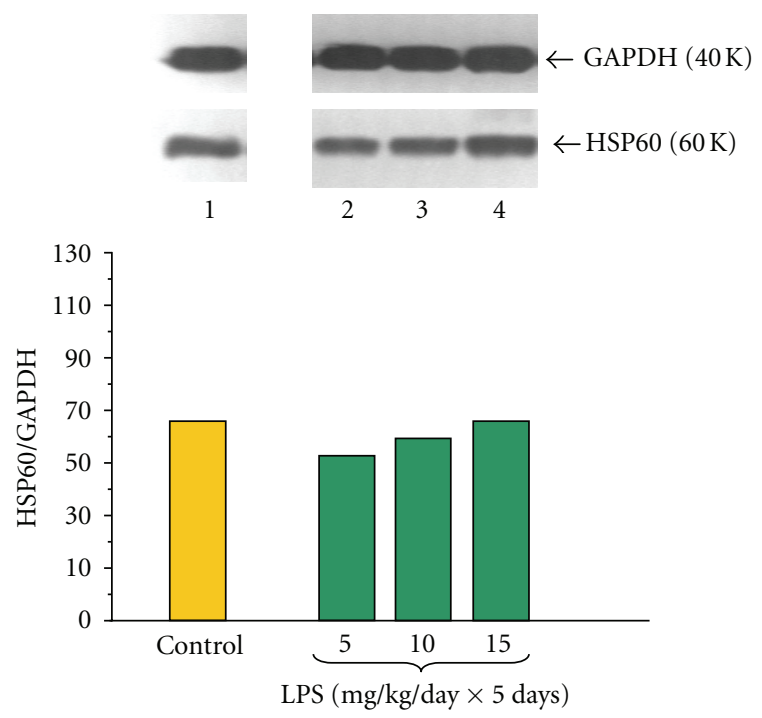

FIGURE 8: Western blot analysis of HSP60 protein level in the adult rat pancreatic acinar cells under basal conditions (lane 1), treated in the infant animals by lipopolysaccharide (Escherichia coli) at the doses of $5 \mathrm{mg} / \mathrm{kg} /$ day $\times 5$ days (lane 2 ), $10 \mathrm{mg} / \mathrm{kg} /$ day $\times 5$ days (lane 3 ) and $15 \mathrm{mg} / \mathrm{kg} /$ day $\times 5$ days (lane 4 ) after 5 hours of incubation. The blots were stripped and probed with GAPDH to document equal protein loading. All presented results were obtained in 4 consecutive experiments and are representative of the observed phenomenon.

(Figure 9). The most pronounced protein levels were detected in the cell culture obtained from animals treated with LPS at doses of 10 or $15 \mathrm{mg} / \mathrm{kg}$. In these groups the distinct increase of HSP60/GAPDH ratio up to $109.0 \pm 0.4$ and $129.0 \pm 0.5$ was noticed, respectively (Figure 9).

The proapoptotic initiator caspase- 9 protein level was not detected in pancreatic acinar cells obtained from adult animals in untreated control cultures (Figures 10 and 11). Endotoxemia in the newborn rats due to increasing doses of LPS $(5,10$ or $15 \mathrm{mg} / \mathrm{kg} /$ day $\times 5$ days $)$ was stimulatory factor for caspase- 9 expression. The ratio of caspase-9/GAPDH reached $37.0 \pm 0.2$ (Figure 10 ).

Incubation of the pancreatic acinar cells with caerulein $\left(10^{-8} \mathrm{M}\right)$ caused a significant increase of caspase- 9 protein level. The ratio of caspase-9/GAPDH protein in this group was $40.0 \pm 0.2$ after 5 hours of incubation (Figure 11).

Foregoing endotoxemia evoked by increasing doses of LPS $(5,10$ or $15 \mathrm{mg} / \mathrm{kg} /$ day $\times 5$ days $)$ caused marked and dose-dependent upregulation of caspase- 9 protein level in the pancreatic acini incubated with caerulein $\left(10^{-8} \mathrm{M}\right)$ as compared to the caerulein-treated group alone with the highest expression values detected in the acini cultures from animals treated with LPS at doses of 10 or $15 \mathrm{mg} / \mathrm{kg} /$ day. The ratio in these groups for caspase-9/GAPDH reached $62.0 \pm 0.3$ and $70.0 \pm 0.3$, respectively (Figure 11).

Caspase- 3 protein was not detected in pancreatic acinar cells obtained from adult animals in control samples (Figures 12 and 13). We have detected elevated level of caspase-3 protein in the acini isolated from animals subjected to the endotoxemia in the infancy due to increasing doses of LPS

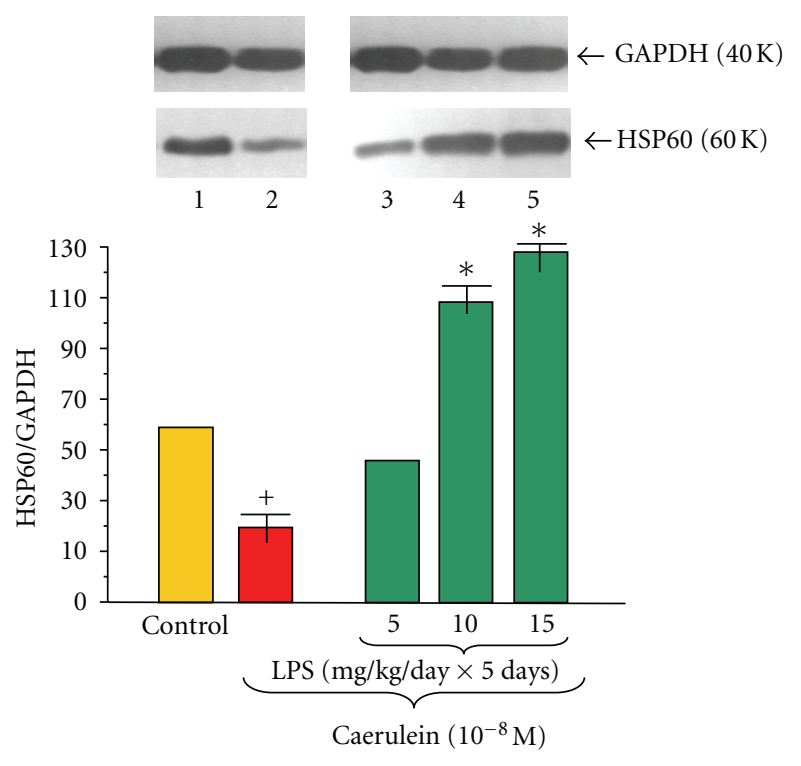

FIGURE 9: Western blot analysis of HSP60 protein level in the adult rat pancreatic acinar cells under basal conditions (lane 1), stimulated in vitro by caerulein at the dose of $10^{-8} \mathrm{M}$ (lane 2), treated in the infant animals by lipopolysaccharide (Escherichia coli) at the doses of $5 \mathrm{mg} / \mathrm{kg} /$ day $\times 5$ days + caerulein $10^{-8} \mathrm{M}$ (lane 3 ), $10 \mathrm{mg} / \mathrm{kg} /$ day $\times 5$ days + caerulein $10^{-8} \mathrm{M}$ (lane 4 ), and $15 \mathrm{mg} / \mathrm{kg} /$ day $\times 5$ days + caerulein $10^{-8} \mathrm{M}$ (lane 5 ) after 5 hours of incubation. Cross indicates significant $(P<0.05)$ change, as compared to the control group. Asterisk indicates significant $(P<0.05)$ change, as compared to the value obtained from the rats treated by increasing doses of LPS $(10$ or $15 \mathrm{mg} / \mathrm{kg} /$ day $\times$ 5 days) in combination with caerulein $\left(10^{-8} \mathrm{M}\right)$, as compared to the caerulein $\left(10^{-8} \mathrm{M}\right)$ alone stimulation. The blots were stripped and probed with GAPDH to document equal protein loading. All presented results were obtained in 4 consecutive experiments and are representative of the observed phenomenon.

$(5,10$ or $15 \mathrm{mg} / \mathrm{kg} /$ day $\times 5$ days $)$ with the ratio of caspase3/GAPDH reaching $113.0 \pm 0.4$ (Figure 12).

Application of caerulein $\left(10^{-8} \mathrm{M}\right)$ to the acinar cells significantly upregulated pro-apoptotic caspase-3 protein level. The ratio of caspase-3/GAPDH was at the level of $118.0 \pm 0.4$ after 5 hours of incubation (Figure 13).

Prior to LPS $(5,10$ or $15 \mathrm{mg} / \mathrm{kg} /$ day $\times 5$ days $)$ endotoxemia resulted in significant and dose-dependent increase of caspase-3 protein level in the acini cultures incubated with caerulein $\left(10^{-8} \mathrm{M}\right)$ as compared to the caerulein-treated group alone. The strongest signals were detected in the cell cultures obtained from the rats treated with LPS at the doses of 10 or $15 \mathrm{mg} / \mathrm{kg} / \mathrm{day}$. The ratio of caspase-3/GAPDH in these groups extended to $188.0 \pm 0.4$ and $209.0 \pm 0.5$, respectively (Figure 13).

\section{Discussion}

Acute pancreatitis (AP) is a pancreatic nonspecific inflammatory process resulting from the activation of many pathological mechanisms such as obstruction of pancreatic duct, acinar oversecretion, and pancreatic ischemia [21-24]. 


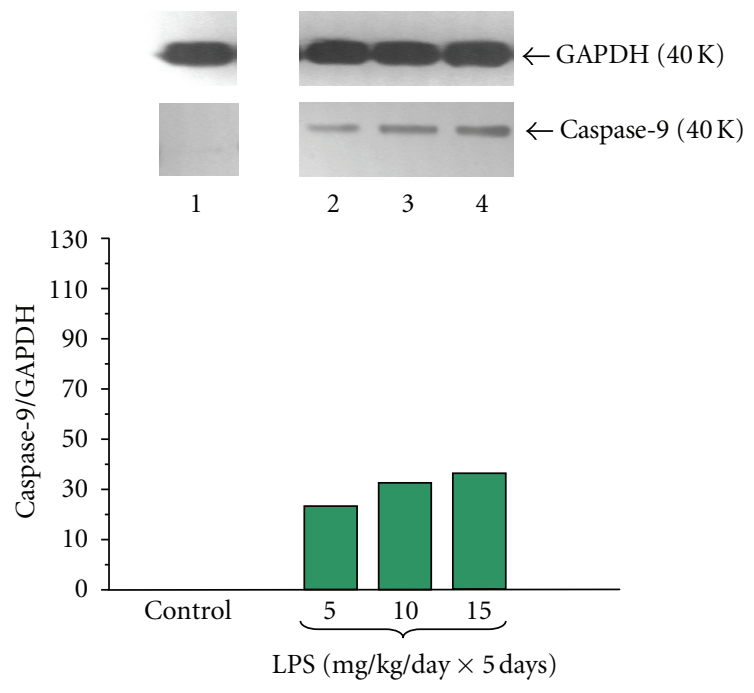

FIgURE 10: Western blot analysis of proapoptotic initiator caspase9 protein level in the adult rat pancreatic acinar cells under basal conditions (lane 1), treated in the infant animals by lipopolysaccharide (Escherichia coli) at the doses of $5 \mathrm{mg} / \mathrm{kg} / \mathrm{day} \times 5$ days (lane 2 ), $10 \mathrm{mg} / \mathrm{kg} /$ day $\times 5$ days (lane 3 ), and $15 \mathrm{mg} / \mathrm{kg} /$ day $\times 5$ days (lane 4) after 5 hours of incubation. The blots were stripped and probed with GAPDH to document equal protein loading. All presented results were obtained in 4 consecutive experiments and are representative of the observed phenomenon.

As the result of above processes the innate immune system is involved in development of inflammatory cascade. Tolllike receptors (TLRs) are suspected to trigger this reaction. It is currently thought that TLRs play an important role in the recognition of endogenous or exogenous antigens and in the initiation of signal transduction for inflammatory reaction during AP [36-38]. Therefore, investigating the tissue-specific expression of these receptors in the pancreas and exploring their role could be important for clarifying the pathogenesis of AP.

In this study we demonstrate the presence of TLR4 on pancreatic acinar cells obtained from the adult rats. In the normal pancreas TLR4 are mainly localized in the epithelial (pancreatic duct epithelium) and endothelial tissue (arteries, veins, and microvascular endothelium) [39, 40]. Herein we have observed that TLR4 protein level in the pancreatic acini was dose-dependently increased in the animals, which have been treated in the early period of life with increasing doses of LPS (Escherichia coli). Since LPS has been identified as a ligand for TLR4, it is generally agreed that TLRs are upregulated under inflammatory conditions and downregulated by immunosuppression [2-4, 41-43]. In our study exposure of the pancreatic acinar cells to caerulein caused upregulation of TLR4 protein level. It was reported that these receptors have been rapidly upregulated during the early stage of rat caerulein-induced pancreatitis (CIP) and that might be associated with induction of apoptosis via the activation of both intrinsic and extrinsic apoptotic signaling pathways $[39,43,44]$. On the other hand, these receptors are downregulated in the late phase of severe acute pancreatitis (SAP) [45]. Moreover, TLR4 activity is associated with
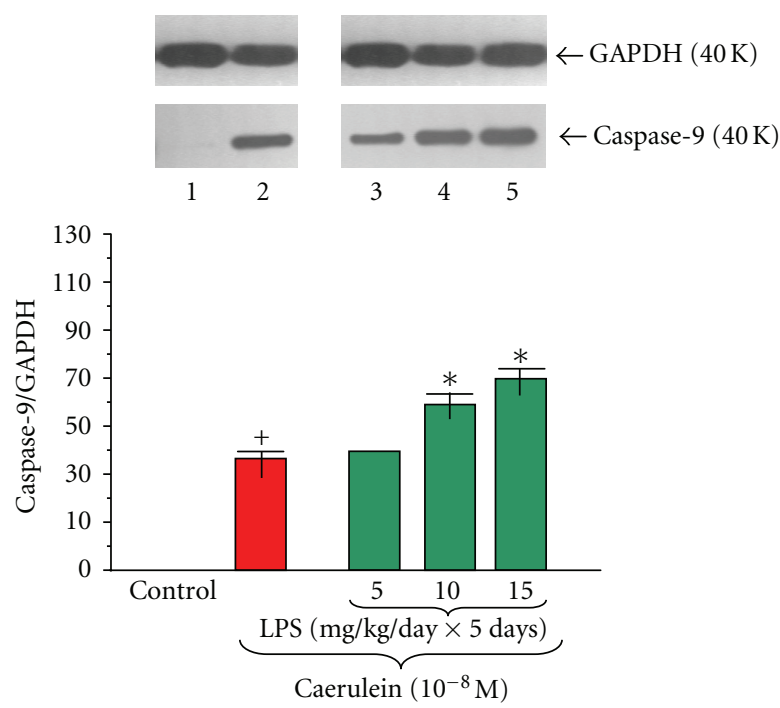

FIGURE 11: Western blot analysis of proapoptotic initiator caspase9 protein level in the adult rat pancreatic acinar cells under basal conditions (lane 1), stimulated in vitro by caerulein at the dose of $10^{-8} \mathrm{M}$ (lane 2), treated in the infant animals by lipopolysaccharide (Escherichia coli) at the doses of $5 \mathrm{mg} / \mathrm{kg} /$ day $\times 5$ days + caerulein $10^{-8} \mathrm{M}$ (lane 3 ), $10 \mathrm{mg} / \mathrm{kg} /$ day $\times 5$ days + caerulein $10^{-8} \mathrm{M}$ (lane 4 ), and $15 \mathrm{mg} / \mathrm{kg} /$ day $\times 5$ days + caerulein $10^{-8} \mathrm{M}$ (lane 5 ) after 5 hours of incubation. Cross indicates significant $(P<0.05)$ change, as compared to the control group. Asterisk indicates significant $(P<0.05)$ change, as compared to the value obtained from the rats treated by increasing doses of LPS $(10$ or $15 \mathrm{mg} / \mathrm{kg} / \mathrm{day} \times$ 5 days) in combination with caerulein $\left(10^{-8} \mathrm{M}\right)$, as compared to the caerulein $\left(10^{-8} \mathrm{M}\right)$ alone stimulation. The blots were stripped and probed with GAPDH to document equal protein loading. All presented results were obtained in 4 consecutive experiments and are representative of the observed phenomenon.

the increased apoptosis [46-51]. Treatment of acini with caerulein resulted in the dose-dependent increase of TLR4 protein level in the rats subjected to endotoxemia in the suckling period of life.

Acinar cell death and parenchymal necrosis is a major cause of severe complications and mortality in human pancreatitis $[52,53]$. In AP acinar cells die through both necrosis and apoptosis. The severity of experimental pancreatitis correlates directly with the intensity of necrosis and, inversely, with apoptosis [53-55]. Bax and Bcl-2 family proteins are important regulators of cell apoptosis and their ratio determines the cell susceptibility to this process [56, 57]. Thus, elucidation of the mechanisms mediating acinar cells death in AP is important for understanding of the regulation of this disease and clinical relevance.

In present study we have demonstrate antiapoptotic mitochondrial molecule $\mathrm{Bcl}-2$ in pancreatic acinar cells to be dose-dependently reduced in the group of rats treated at early period of life with highest dose of LPS. Application of caerulein to the acinar cells resulted in the upregulation of Bcl-2 and decrease of Bax protein levels, as compared to the control cells. AP has been shown to upregulate Bcl2, whereas Bax mRNA was inhibited [58-60]. Our results revealed that in the pancreatic acinar cells obtained from 


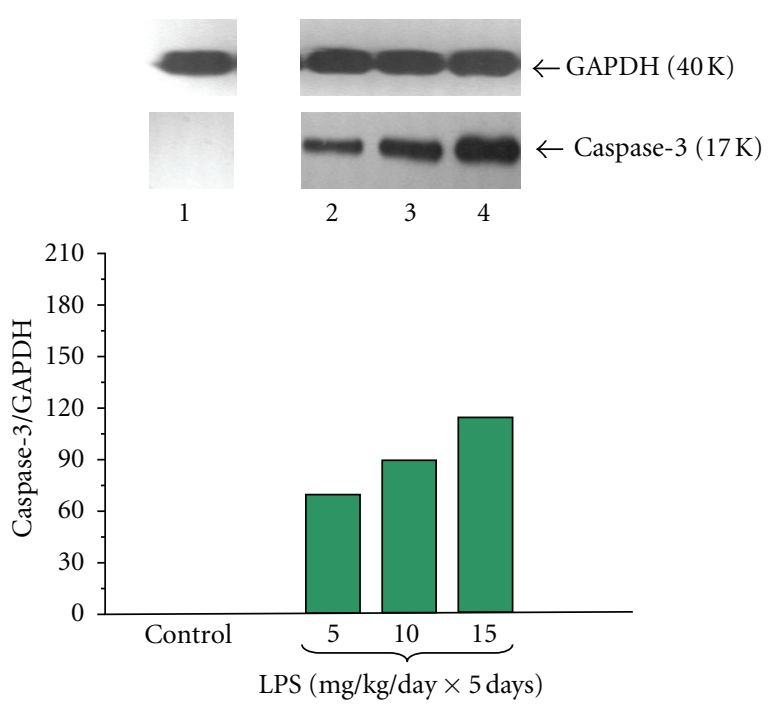

FIGURE 12: Western blot analysis of apoptosis executioner caspase3 protein level in the adult rat pancreatic acinar cells under basal conditions (lane 1), treated in the infant animals by lipopolysaccharide (Escherichia coli) at the doses of $5 \mathrm{mg} / \mathrm{kg} /$ day $\times 5$ days (lane 2), $10 \mathrm{mg} / \mathrm{kg} /$ day $\times 5$ days (lane 3 ), and $15 \mathrm{mg} / \mathrm{kg} /$ day $\times 5$ days (lane 4) after 5 hours of incubation. The blots were stripped and probed with GAPDH to document equal protein loading. All presented results were obtained in 4 consecutive experiments and are representative of the observed phenomenon.

the rats subjected in infancy to endotoxemia, caerulein caused dose-dependent: downregulation of antiapoptotic $\mathrm{Bcl}-2$ and upregulation of pro-apoptotic Bax protein levels, as compared to the caerulein-treated cells alone, suggesting susceptibility of those cultures to apoptosis. Our assumption was confirmed with DNA fragmentation assay. Pancreatic acinar cells obtained from the rats subjected in infancy to endotoxemia and stimulated in vitro with caerulein manifested typical for apoptosis pattern of DNA damage.

We have found HSP60 protein in pancreatic acinar cells obtained from adult animals and this confirmed the previous observations concerning the presence of HSP60 protein in the pancreas and in the pancreatic cell line; AR42J $[30,31,61-63]$. This expression of HSP60 in pancreatic tissues has been decreased with prolonged stimulation with LPS [64]. Ohashi et al. [14] claimed that TLR4 mediates HSP60 signaling, as a putative endogenous ligand of the TLR4 complex. We have observed that exposition of the acinar cells in culture to caerulein decreased protein level of HSP60, as compared to the control group. This is in agreement with Rakonczay et al. [65] who have shown that repeated injections of supramaximal doses of CCK to the rat could reduce pancreatic HSP60. Our previous data also demonstrated that caerulein stimulation is able to reduce mRNA signal for HSP60 in the AR42J cells $[62,63]$. It is interesting that in the rat pancreas caerulein in time- and dose-dependent manner increases mRNA but paradoxically reduces protein level of rat pancreatic HSP60 [64, 66]. Endotoxemia in the suckling rats resulted in the increase of HSP60 protein level in pancreatic acinar cells, obtained from
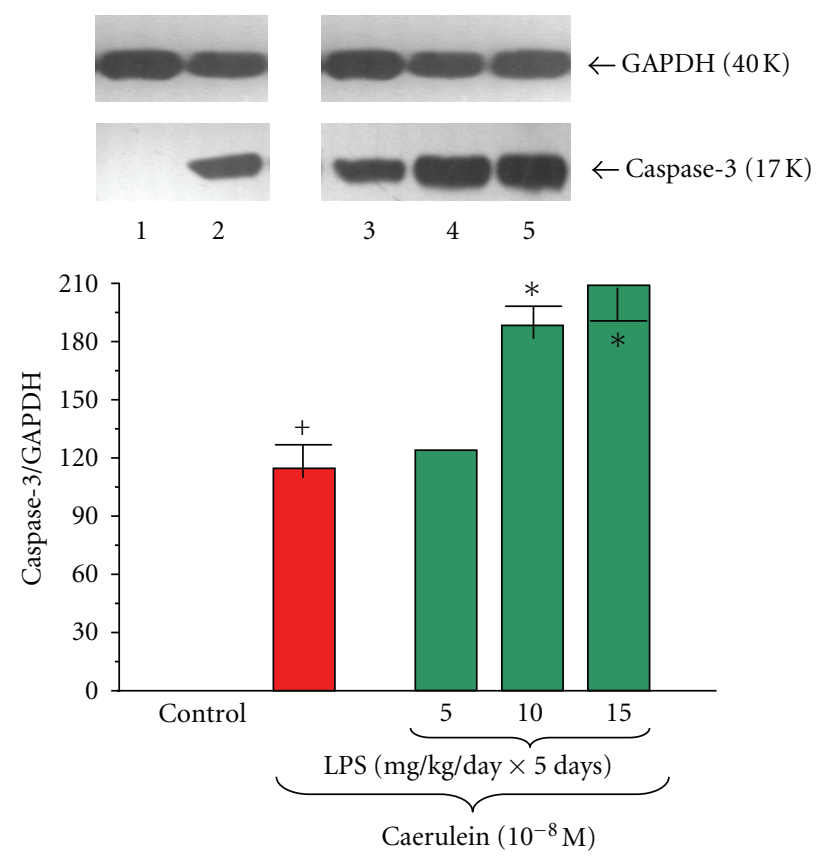

FIGURE 13: Western blot analysis of apoptosis executioner caspase3 protein level in the adult rat pancreatic acinar cells under basal conditions (lane 1), stimulated in vitro by caerulein at the dose of $10^{-8} \mathrm{M}$ (lane 2), treated in the infant animals by lipopolysaccharide (Escherichia coli) at the doses of $5 \mathrm{mg} / \mathrm{kg} /$ day $\times 5$ days + caerulein $10^{-8} \mathrm{M}$ (lane 3 ), $10 \mathrm{mg} / \mathrm{kg} /$ day $\times 5$ days + caerulein $10^{-8} \mathrm{M}$ (lane 4 ), and $15 \mathrm{mg} / \mathrm{kg} /$ day $\times 5$ days + caerulein $10^{-8} \mathrm{M}$ (lane 5 ) after 5 hours of incubation. Cross indicates significant $(P<0.05)$ change, as compared to the control group. Asterisk indicates significant $(P<0.05)$ change, as compared to the value obtained from the rats treated by increasing doses of LPS (10 or $15 \mathrm{mg} / \mathrm{kg} /$ day $\times$ 5 days) in combination with caerulein $\left(10^{-8} \mathrm{M}\right)$, as compared to the caerulein $\left(10^{-8} \mathrm{M}\right)$ alone stimulation. The blots were stripped and probed with GAPDH to document equal protein loading. All presented results were obtained in 4 consecutive experiments and are representative of the observed phenomenon.

adult animals, and subjected to caerulein overstimulation. This is in agreement with previous report showing upregulation of pancreatic HSP60 after treatment with combination of caerulein and LPS [61]. On the other hand, different researchers showed time- and dose-dependent increases of mRNA that were followed by paradoxical reduction of protein level of rat pancreatic HSP60 after application of caerulein and LPS [64]. Our previous studies have shown that endotoxemia induced in the early period of life limits $\mathrm{AP}$ and reduces the pancreatic exocrine function in response to caerulein both in vivo and in vitro models at adult age [29-32]. It is possible that pancreatoprotective effects, like cytokine modulation, superoxide dismutase (SOD) activity, and decrease of pancreatic enzyme secretion, are related to the upregulation of HSP60 protein level in the pancreatic acini. Otaka et al. [18] and Rakonczay et al. [19, 20, 65] showed that an increase of HSP60 transcription and production and/or in conjunction with the cytokine modulation and free radical scavenger enzymes (e.g., SOD) activities could be important of "adaptive cytoprotection" in the AP. 
Le Gall and Bendayan [16], Li et al. [17] demonstrated hypothesis that the HSP60 would assist the proper folding and assembly of pancreatic secretory proteins and could also prevent their autoactivation before secretion and must be important for quality control and integrity of it.

In the present study we have not detected pro-apoptotic initiator caspase- 9 and apoptosis executioner caspase- 3 protein expression on pancreatic acinar cells obtained from the adult rats. However Gukovskaya et al. [67] and Mareninova et al. [68] have demonstrated the presence of active caspases9 and -3 in the normal pancreatic tissue and pancreatic acini. We have shown that endotoxemia in the newborn rats, stimulated both caspases expression in acinar cells obtained from adult animals. This is in agreement with previous study showing that LPS treatment increased caspase-3 activity in the pancreas [69]. We have demonstrated that exposure of the acinar cells to caerulein $\left(10^{-8} \mathrm{M}\right)$ upregulated proapoptotic caspase- 9 and -3 protein level, as compared to the control group, what is in agreement with the observation of Gukovskaya et al. [67] and Mareninova et al. [68]. In experimental models of AP, acinar cells have been shown to die through necrosis and apoptosis [68]. We have found that endotoxemia in the sucking animals evoked by increasing doses of LPS caused dose-dependently upregulation of proapoptotic caspase- 9 and executioner caspase-3 protein level in the pancreatic acini incubated with caerulein. Laine et al. [70] demonstrated that the LPS causes release of pancreatic phospholipase $\mathrm{A}_{2}\left(\mathrm{PLA}_{2}\right)$ into blood, its activation in pancreatic tissue and apoptosis of acinar cells. Kimura et al. [71] showed that LPS pretreatment increased remarkably the incidence of acinar cells apoptosis in AP. These results suggest that the pathological features of this disease might be modified by the presence of nonfatal endotoxemia through the induction of acinar cells apoptosis.

In conclusion, our data indicate that exposure of the infant rats to LPS promoted the induction of HSP60 via TLR4 in their adult life and, in turn, activated Bax/Bcl-2 and caspase- 9 and -3. It is likely that this process could take a part in the LPS-induced protection of the pancreatic tissue against acute damage produced by caerulein overstimulation.

\section{Conflict of Interests}

The authors declare that they have no conflict of interests.

\section{Acknowledgments}

This study was supported by a Grant from Faculty of Health Sciences, School of Medicine, Jagiellonian University; no. K/ZBW/000167.

\section{References}

[1] M. P. Glauser, G. Zanetti, J. D. Baumgartner, and J. Cohen, "Septic shock: pathogenesis," The Lancet, vol. 338, no. 8769, pp. 732-736, 1991.

[2] J. Reis, X. Q. Guan, A. F. Kisselev et al., "LPS-induced formation of immunoproteasomes: TNF- $\alpha$ and nitric oxide production are regulated by altered composition of proteasome-active sites," Cell Biochemistry and Biophysics, vol. 60, no. 1-2, pp. 77$88,2011$.

[3] J. B. Soares, P. Pimentel-Nunes, R. Roncon-Albuquerque, and A. Leite-Moreira, "The role of lipopolysaccharide/tolllike receptor 4 signaling in chronic liver diseases," Hepatology International, vol. 4, no. 4, pp. 659-672, 2010.

[4] C. R. Raetz, "Bacterial endotoxins: extraordinary lipids that activate eucaryotic signal transduction," Journal of Bacteriology, vol. 175, no. 18, pp. 5745-5753, 1993.

[5] S. Akira, S. Uematsu, and O. Takeuchi, "Pathogen recognition and innate immunity," Cell, vol. 124, no. 4, pp. 783-801, 2006.

[6] A. Aderem and R. J. Ulevitch, "Toll-like receptors in the induction of the innate immune response," Nature, vol. 406, no. 6797, pp. 782-787, 2000.

[7] B. A. Beutler, "TLRs and innate immunity,” Blood, vol. 113, no. 7, pp. 1399-1407, 2009.

[8] P. Pimentel-Nunes, J. B. Soares, R. Roncon-Albuquerque, M. Dinis-Ribeiro, and A. F. Leite-Moreira, "Toll-like receptors as therapeutic targets in gastrointestinal diseases," Expert Opinion on Therapeutic Targets, vol. 14, no. 4, pp. 347-368, 2010.

[9] H. M. Kim, B. S. Park, J. Kim et al., "Crystal structure of the TLR4-MD-2 complex with bound endotoxin antagonist eritoran," Cell, vol. 130, no. 5, pp. 906-917, 2007.

[10] C. E. Bryant, D. R. Spring, M. Gangloff, and N. J. Gay, "The molecular basis of the host response to lipopolysaccharide," Nature Reviews Microbiology, vol. 8, no. 1, pp. 8-14, 2010.

[11] A. Tsung, R. Sahai, H. Tanaka et al., "The nuclear factor HMGB1 mediates hepatic injury after murine liver ischemiareperfusion," Journal of Experimental Medicine, vol. 201, no. 7, pp. 1135-1143, 2005.

[12] D. Jiang, J. Liang, J. Fan et al., "Regulation of lung injury and repair by Toll-like receptors and hyaluronan," Nature Medicine, vol. 11, no. 11, pp. 1173-1179, 2005.

[13] H. Shi, M. V. Kokoeva, K. Inouye, I. Tzameli, H. Yin, and J. S. Flier, "TLR4 links innate immunity and fatty acid-induced insulin resistance," Journal of Clinical Investigation, vol. 116, no. 11, pp. 3015-3025, 2006.

[14] K. Ohashi, V. Burkart, S. Flohe, and H. Kolb, "Cutting edge: heat shock protein 60 is a putative endogenous ligand of the toll-like receptor-4 complex," Journal of Immunology, vol. 164, no. 2, pp. 558-561, 2000.

[15] G. Gruden, G. Bruno, N. Chaturvedi et al., "ANTI-HSP60 and ANTI-HSP70 antibody levels and micro/ macrovascular complications in type 1 diabetes: the EURODIAB Study," Journal of Internal Medicine, vol. 266, no. 6, pp. 527-536, 2009.

[16] I. M. Le Gall and M. Bendayan, "Possible association of chaperonin 60 with secretory proteins in pancreatic acinar cells," Journal of Histochemistry and Cytochemistry, vol. 44, no. 7, pp. 743-749, 1996.

[17] Y. Li, D. Gingras, I. Londono, and M. Bendayan, "Expression differences in mitochondrial and secretory chaperonin 60 (Cpn60) in pancreatic acinar cells," Cell Stress Chaperones, vol. 14, pp. 199-206, 2003.

[18] M. Otaka, A. Okuyama, S. Otani et al., "Differential induction of HSP60 and HSP72 by different stress situations in rats: correlation with cerulein-induced pancreatitis," Digestive Diseases and Sciences, vol. 42, no. 7, pp. 1473-1479, 1997.

[19] Z. Rakonczay Jr., T. Takács, B. Ivanyi et al., "The effects of hypo- and hyperthermic pretreatment on sodium taurocholate-induced acute pancreatitis in rats," Pancreas, vol. 24, pp. 83-89, 2002. 
[20] Z. Rakonczay Jr., T. Takács, I. Boros, and J. Lonovics, "Heat shock proteins and the pancreas," Journal of Cellular Physiology, vol. 195, no. 3, pp. 383-391, 2003.

[21] N. Chen, J. Zou, S. Wang et al., "Designing protease sensors for real-time imaging of trypsin activation in pancreatic cancer cells," Biochemistry, vol. 48, no. 15, pp. 3519-3526, 2009.

[22] J. L. Frossard, M. L. Steer, and C. M. Pastor, "Acute pancreatitis," The Lancet, vol. 371, no. 9607, pp. 143-152, 2008.

[23] M. G. Raraty, J. A. Murphy, E. Mcloughlin, D. Smith, D. Criddle, and R. Sutton, "Mechanisms of acinar cell injury in acute pancreatitis," Scandinavian Journal of Surgery, vol. 94, no. 2, pp. 89-96, 2005.

[24] M. Ohmuraya and K. Yamamura, "Autophagy and acute pancreatitis: a novel autophagy theory for trypsinogen activation," Autophagy, vol. 4, no. 8, pp. 1060-1062, 2008.

[25] J. Jaworek, B. Jachimczak, J. Bonior et al., "Protective role of endogenous nitric oxide (NO) in lipopolysaccharide-induced pancreatic damage. (A new experimental model of acute pancreatitis)," Journal of Physiology and Pharmacology, vol. 51, no. 1, pp. 85-102, 2000.

[26] J. Jaworek, B. Jachimczak, R. Tomaszewska et al., "Protective action of lipopolysaccharides in rat caerulein-induced pancreatitis: role of nitric oxide," Digestion, vol. 62, no. 1, pp. 1-13, 2000.

[27] J. Jaworek, J. Bonior, R. Tomaszewska et al., "Involvement of cyclooxygenase-derived prostaglandin E2 and nitric oxide in the protection of rat pancreas afforded by low dose of lipopolysaccharide," Journal of Physiology and Pharmacology, vol. 52, no. 1, pp. 107-126, 2001.

[28] J. Jaworek, J. Bonior, K. Nawrot et al., "Intracerebroventricular administration of bacterial lipopolysaccharide prevents the development of acute experimental pancreatitis in the rat," Medical Science Monitor, vol. 8, no. 4, pp. BR136-BR143, 2002.

[29] J. Jaworek, S. J. Konturek, M. Macko et al., "Endotoxemia in newborn rats attenuates acute pancreatitis at adult age," Journal of Physiology and Pharmacology, vol. 58, no. 1, pp. 131147, 2007.

[30] J. Jaworek, A. Leja-Szpak, K. Nawrot-Porąbka et al., "Effect of neonatal endotoxemia on the pancreas of adult rats," Journal of Physiology and Pharmacology, vol. 59, no. 4, pp. 87-102, 2008.

[31] J. Bonior, J. Jaworek, M. Kot, S. J. Konturek, and W. W. Pawlik, "Endotoxemia in the infant rats modulates HSP60 protein level in the pancreatic acinar cells," Journal of Physiology and Pharmacology, vol. 58, no. 3, pp. 189-198, 2007.

[32] J. Jaworek, K. Nawrot-Porąbka, A. Leja-Szpak et al., "Exposition of newborn rats to bacterial endotoxin impairs pancreatic enzyme secretion at adult age," Journal of Physiology and Pharmacology, vol. 58, no. 2, pp. 287-302, 2007.

[33] D. Amsterdam, T. E. Solomon, and J. D. Jamieson, "Sequential dissociation of the exocrine pancreas into lobules, acini, and individual cells," Methods in Cell Biology, vol. 20, pp. 362-378, 1978.

[34] J. Jaworek, J. Bilski, B. Jachimczak et al., "The effects of ammonia on pancreatic enzyme secretion in vivo and in vitro," Journal of Physiology and Pharmacology, vol. 51, no. 2, pp. 315$332,2000$.

[35] J. Sambrook, E. F. Fritsch, T. Maniatis, and C. Nolan, Eds., Molecular Clonng, A Laboratory Manual, Cold Spring Harbor Laboratory Press, New York, NY, USA, 1989.

[36] R. L. Modlin, "Mammalian Toll-like receptors," Annals of Allergy, Asthma and Immunology, vol. 88, no. 6, pp. 543-587, 2002.

[37] E. Lien and R. R. Ingalls, "Toll-like receptors," Critical Care Medicine, vol. 30, no. 1, pp. S1-S11, 2002.
[38] S. Y. C. Wong, "Innate immune trouble detectors," Trends in Immunology, vol. 22, no. 5, pp. 235-236, 2001.

[39] Y. Li, Z. G. Zhou, Q. J. Xia et al., “Toll-like receptor 4 detected in exocrine pancreas and the change of expression in ceruleininduced pancreatitis," Pancreas, vol. 30, no. 4, pp. 375-381, 2005.

[40] H. K. Gao, Z. G. Zhou, Y. Li, and al et, "Immunohistochemical localization of Toll-like receptors 4 in pancreas," West China Medical Journal, vol. 19, no. 2, pp. 241-242, 2004.

[41] M. Hausmann, S. Kiessling, S. Mestermann et al., "Tolllike receptors 2 and 4 are up-regulated during intestinal inflammation," Gastroenterology, vol. 122, no. 7, pp. 19872000, 2002.

[42] H. Miyaso, Y. Morimoto, M. Ozaki et al., "Obstructive jaundice increases sensitivity to lipopolysaccharide via TLR4 up-regulation: possible involvement in gut-derived hepatocyte growth factor-protection of hepatocytes," Journal of Gastroenterology and Hepatology, vol. 20, pp. 1859-1866, 2005.

[43] H. Ikushima, T. Nishida, K. Takeda et al., "Expression of Toll-like receptors 2 and 4 is downregulated after operation," Surgery, vol. 135, no. 4, pp. 376-385, 2004.

[44] S. Q. Ding, Y. Li, Z. G. Zhou, C. Wang, L. Zhan, and B. Zhou, "Toll-like receptor 4-mediated apoptosis of pancreatic cells in cerulein-induced acute pancreatitis in mice," Hepatobiliary and Pancreatic Diseases International, vol. 9, no. 6, pp. 645650, 2010.

[45] H. Sawa, T. Ueda, Y. Takeyama et al., "Role of toll-like receptor 4 in the pathophysiology of severe acute pancreatitis in mice," Surgery Today, vol. 37, no. 10, pp. 867-873, 2007.

[46] B. Salaun, P. Romero, and S. Lebecque, "Toll-like receptor's two-edged sword: when immunity meets apoptosis," European Journal of Immunology, vol. 37, no. 12, pp. 3311-3318, 2007.

[47] L. C. Hsu, J. M. Park, K. Zhang et al., “The protein kinase PKR is required for macrophage apoptosis after activation of Tolllike receptor 4," Nature, vol. 428, no. 6980, pp. 341-345, 2004.

[48] D. D. Bannerman and S. E. Goldblum, "Mechanisms of bacterial lipopolysaccharide-induced endothelial apoptosis," American Journal of Physiology. Lung Cellular and Molecular Physiology, vol. 284, no. 6, pp. L899-L914, 2003.

[49] K. Ruckdeschel, G. Pfaffinger, R. Haase et al., "Signaling of apoptosis through TLRs critically involves toll/IL-1 receptor domain-containing adapter inducing IFN-beta, but not MyD88, in bacteria-infected murine macrophages," Journal of Immunology, vol. 173, no. 5, pp. 3320-3328, 2004.

[50] D. Y. Jung, H. Lee, B. Y. Jung et al., "TLR4, but not TLR2, signals autoregulatory apoptosis of cultured microglia: a critical role of IFN-beta; as a decision maker," Journal of Immunology, vol. 174, no. 10, pp. 6467-6476, 2005.

[51] O. Equils, D. Lu, M. Gatter et al., "Chlamydia heat shock protein 60 induces trophoblast apoptosis through TLR4," Journal of Immunology, vol. 177, no. 2, pp. 1257-1263, 2006.

[52] S. J. Pandol, A. K. Saluja, C. W. Imrie, and P. A. Banks, "Acute pancreatitis: bench to the bedside," Gastroenterology, vol. 132, no. 3, pp. 1127-1151, 2007.

[53] A. S. Gukovskaya and S. J. Pandol, "Cell death pathways in pancreatitis and pancreatic cancer," Pancreatology, vol. 4, no. 6, pp. 567-586, 2004.

[54] M. Bhatia, "Apoptosis versus necrosis in acute pancreatitis," American Journal of Physiology. Gastrointestinal and Liver Physiology, vol. 286, no. 2, pp. G189-G196, 2004.

[55] A. Saluja, B. Hofbauer, Y. Yamaguchi, K. Yamanaka, and M. Steer, "Induction of apoptosis reduces the severity of caerulein-induced pancreatitis in mice," Biochemical and 
Biophysical Research Communications, vol. 220, no. 3, pp. 875878, 1996.

[56] N. N. Danial and S. J. Korsmeyer, "Cell death: critical control points," Cell, vol. 116, no. 2, pp. 205-219, 2004.

[57] R. Sutton, D. Criddlea, M. G. Raraty, A. Tepikin, J. P. Neoptolemos, and O. H. Petersen, "Signal transduction, calcium and acute pancreatitis," Pancreatology, vol. 3, no. 6, pp. 497-505, 2003.

[58] K. F. Sung, I. V. Odinokova, O. A. Mareninova et al., "Prosurvival Bcl-2 proteins stabilize pancreatic mitochondria and protect against necrosis in experimental pancreatitis," Experimental Cell Research, vol. 315, no. 11, pp. 1975-1989, 2009.

[59] L. Singh, D. K. Bakshi, S. Majumdar, S. K. Arora, R. K. Vasishta, and J. D. Wig, "Mitochondrial dysfunction and apoptosis of acinar cells in chronic pancreatitis," Journal of Gastroenterology, vol. 43, no. 6, pp. 473-483, 2008.

[60] J. H. Yu, H. Kim, and K. H. Kim, "Calcium-dependent apoptotic gene expression in cerulein-treated AR42J cells," Annals of the New York Academy of Sciences, vol. 1010, pp. 6669, 2003.

[61] Y. Y. Li, S. Ochs, Z. R. Gao et al., "Regulation of HSP60 and the role of MK2 in a new model of severe experimental pancreatitis," American Journal of Physiology. Gastrointestinal and Liver Physiology, vol. 297, no. 5, pp. G981-G989, 2009.

[62] J. Bonior, J. Jaworek, S. J. Konturek, and W. W. Pawlik, "Increase of heat shock protein gene expression by melatonin in AR42J cells," Journal of Physiology and Pharmacology, vol. 56, no. 3, pp. 471-481, 2005.

[63] J. Bonior, J. Jaworek, S. J. Konturek, and W. W. Pawlik, "Leptin is the modulator of HSP60 gene expression in AR42J cells," Journal of Physiology and Pharmacology, vol. 57, no. 7, pp. 135143, 2006.

[64] Y. Y. Li, S. Lu, K. Li et al., "Down-regulation of HSP60 expression by RNAi increases lipopolysaccharide- and ceruleininduced damages on isolated rat pancreatic tissues," Cell Stress and Chaperones, vol. 15, no. 6, pp. 965-975, 2010.

[65] Z. Rakonczay Jr., B. Iványi, I. Varga et al., "Nontoxic heat shock protein coinducer BRX-220 protects against acute pancreatitis in rats," Free Radical Biology and Medicine, vol. 32, no. 12, pp. 1283-1292, 2002.

[66] M. Z. Strowski, G. Sparmann, H. Weber et al., "Caerulein pancreatitis increases mRNA but reduces protein levels of rat pancreatic heat shock proteins," American Journal of Physiology, vol. 273, no. 4, pp. G937-G945, 1997.

[67] A. S. Gukovskaya, I. Gukovsky, Y. Jung, M. Mouria, and S. J. Pandol, "Cholecystokinin induces caspase activation and mitochondrial dysfunction in pancreatic acinar cells. Roles in cell injury processes of pancreatitis," Journal of Biological Chemistry, vol. 277, no. 25, pp. 22595-22604, 2002.

[68] O. A. Mareninova, K. F. Sung, P. Hong et al., "Cell death in pancreatitis: caspases protect from necrotizing pancreatitis," Journal of Biological Chemistry, vol. 281, no. 6, pp. 3370-3381, 2006.

[69] A. Vonlaufen, P. A. Phillips, Z. Xu et al., "Withdrawal of alcohol promotes regression while continued alcohol intake promotes persistence of LPS-induced pancreatic injury in alcohol-fed rats," Gut, vol. 60, no. 2, pp. 238-246, 2011.

[70] V. J. Laine, K. M. Nyman, H. J. Peuravuori, K. Henriksen, M. Parvinen, and T. J. Nevalainen, "Lipopolysaccharide induced apoptosis of rat pancreatic acinar cells," Gut, vol. 38, no. 5, pp. 747-752, 1996.

[71] K. Kimura, T. Shimosegawa, R. Abe et al., "Low doses of lipopolysaccharide upregulate acinar cell apoptosis in cerulein pancreatitis," Pancreas, vol. 17, no. 2, pp. 120-126, 1998. 


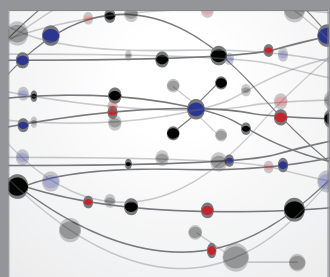

The Scientific World Journal
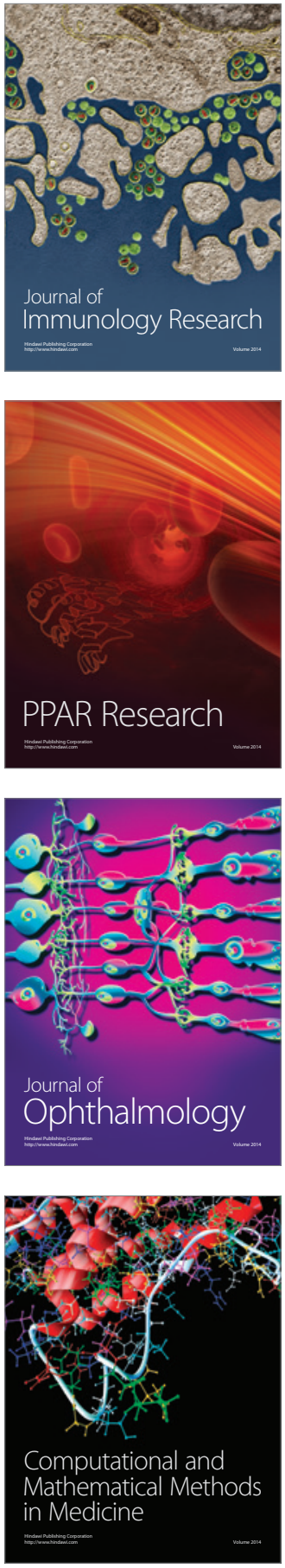

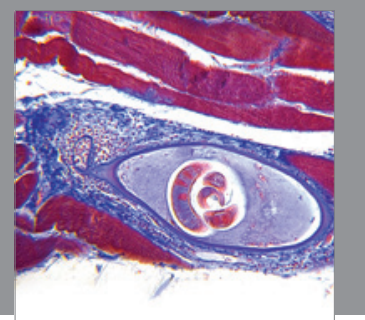

Gastroenterology

Research and Practice
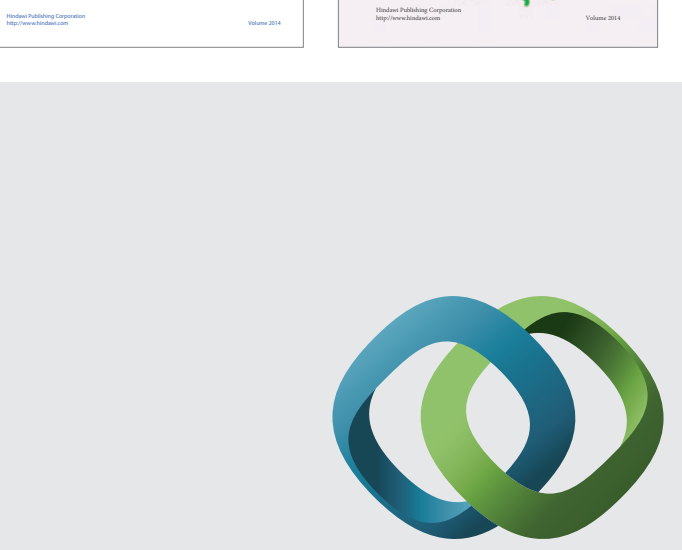

\section{Hindawi}

Submit your manuscripts at

http://www.hindawi.com
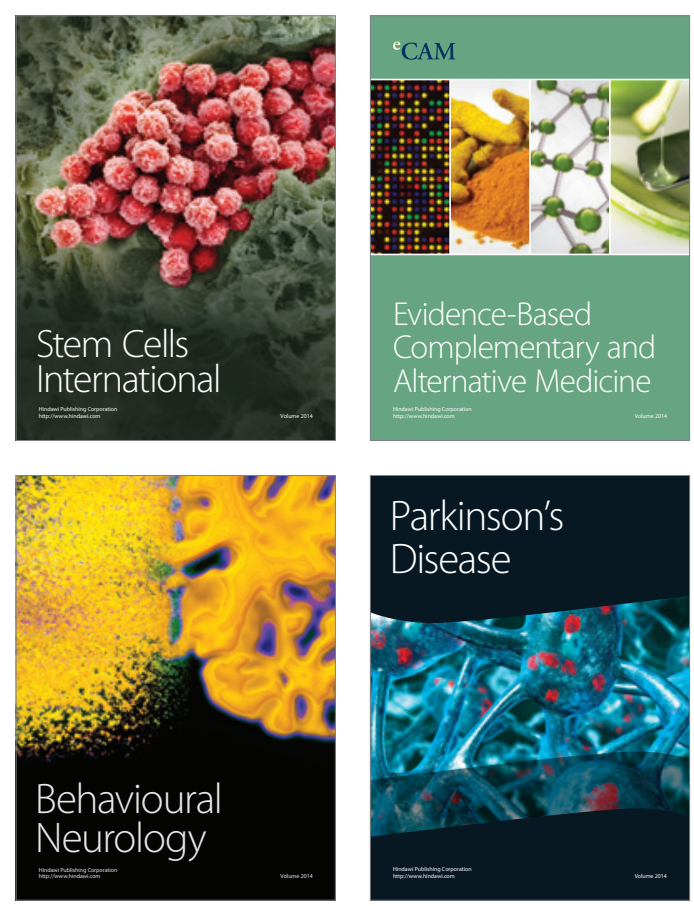

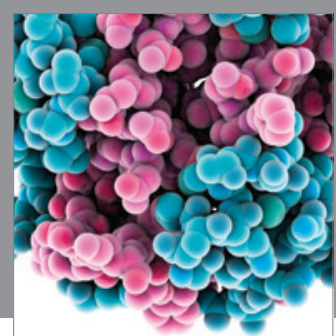

Journal of
Diabetes Research

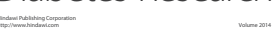

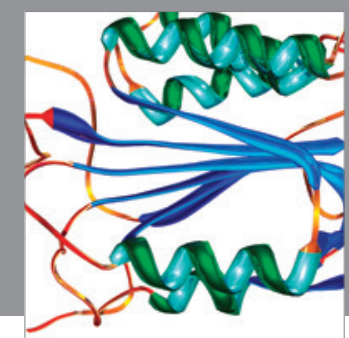

Disease Markers
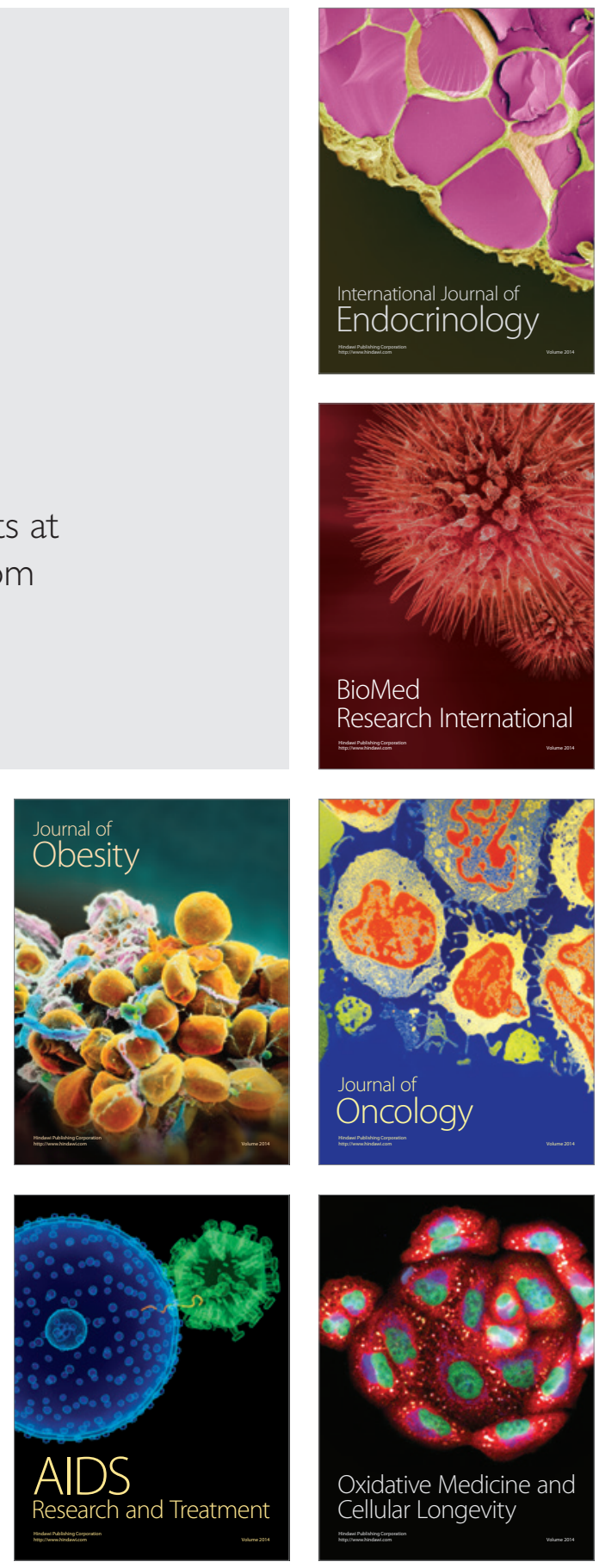